\title{
Correlation and Path Analysis of Green Pod Yield and Its Components in Snap Bean (Phaseolus Vulgaris L.) Genotypes
}

\author{
Yosef Alemu $^{1} *$, Sintayehu Alamirew ${ }^{2}$, Lemma Dessalegn ${ }^{3}$ \\ ${ }^{1}$ Melkassa Agricultural Research Center, Melkassa, Ethiopia \\ ${ }^{2}$ College of Agriculture and Veterinary Medicine, Jimma University, Jimma, Ethiopia \\ ${ }^{3}$ Ethiopian Seed Growers and Producers Association, Addis Ababa, Ethiopia
}

\begin{abstract}
Snap bean is becoming an important vegetable crop in Ethiopia primarily produced for export markets. Although several research results indicated strong association of green pod yield with yield contributing traits in snap bean, limited information is available under Ethiopian condition. Field experiment was conducted to study the nature and extent of association among 16 traits in snap bean genotypes. Positive and significant genotypic correlation was observed between green pod yield with number of pod per plant $\left(\mathrm{r}_{\mathrm{g}}=0.775\right)$, single green pod weight $\left(r_{g}=0.664\right)$, pod dry weight $\left(r_{g}=0.333\right)$, pod length $\left(r_{g}=0.537\right)$ and leaf area per plant $\left(r_{g}=0.665\right)$ while significant negative genotypic correlation was found between green pod yield and days to $50 \%$ flowering $\left(r_{\mathrm{g}}=-0.437\right)$ and days to first picking $\left(r_{\mathrm{g}}=-0.557\right)$. Genotypic path analysis showed that pod number per plant exerted the maximum positive direct effect $(0.688)$ on green pod yield followed by single green pod weight (0.539) while plant height exhibited maximum negative direct effect (-0.458). Generally, traits having positive and significant correlation and high direct effect on green pod yield revealed direct selection of these traits could bring about green pod yield improvement in snap bean.
\end{abstract}

Keywords: Correlation, Genotype, Green Pod Yield, Path Coefficient, Snap Bean.

\section{INTRODUCTION}

Common bean is widely cultivated in the world due to its high market value and good nutritional composition; high protein content in dry seed, and good source of fiber in snap bean. It is the second most important source of protein after maize and the third most important source of calories next to maize and cassava in Sub-Saharan Africa [2]. It is consumed either as dry bean (pulse) or snap bean (fresh vegetable) [16]. Its immature edible pod and ripe seeds contain protein, carbohydrate, fat, fiber, thiamine, riboflavin, calcium and iron.

Snap bean and other beans, such as kidney bean, navy bean and black bean are referred as common bean probably they all derived from a common ancestors [1].Snap bean is strain of common bean which is developed for succulent pods having little fiber through breeding and selection [1].The immature pods and seeds are produced for fresh consumption and processing in the form of canned or frozen products [6].

Production of snap bean in Ethiopia was started in the early 1970s with the purpose of exporting to different market destinations. Different private commercial companies mainly business partners of European companies have been involved in the production of snap bean in Ethiopia during the winter season when their domestic production is limited [8]. Different snap bean types mainly bobby and fine beans have been exported to European and Middle East countries with the highest share among all vegetables $[10,11]$. Non-exportable grades has also been used for local markets and the demand of domestic consumption has been increasing [11].

The area and production of snap bean in Ethiopia during the last ten years (2003-2013) increased by 76. 5\% and $77.1 \%$ respectively [5]. Limited efforts have been made on varietal development to identify suitable varieties for local use and export market. Ethiopian farmers in most cases have been limited to grow introduced, private company owned snap bean cultivars with high seed cost. The introduced cultivars in general require high rates of nitrogen as they have been developed under intensive production systems [8]. Currently, there are only two snap bean varieties nationally released by Melkassa Agricultural Research Center (MARC) and additional four registered by local company for large scale production in the country [14]. 
Yosef Alemu et al. "Correlation and Path Analysis for Green Pod Yield and Its Components in Snap Bean (Phaseolus Vulgaris L.) Genotypes"

Yield is complex quantitative trait which is controlled by several yield related traits and thus information on nature and extent of association among yield contributing traits is useful towards indirect selection for yield improvement. Correlation and path analysis has been used as a tool to generate information on association of yield contributing traits for crop improvement program. Several authors studied association of green pod yield with yield contributing traits in snap bean. For instance, [22] and [4] reported positive correlation of pod number per plant with green pod yield in snap bean where as [15] and [23] reported positive correlation of green pod length and green pod weight with green pod yield respectively. [22] reported positive direct effects of green pod number per plant and single green pod weight on green pod yield per plant. Although several research result indicated the occurrence of strong association between green pod yield and yield contributing traits in snap bean, limited information is available under Ethiopian condition. The objective of the study was to determine the nature and extent of association among sixteen morphological traits of thirty six snap bean genotypes.

\section{MATERIALS AND METHODS}

\section{Experimental Materials and Procedures}

Thirty four snap bean genotypes originally obtained from CIAT and FAO and two commercial cultivars for comparison which have been widely produced and exported to different market destinations were used in the study. List of the thirty six snap bean genotypes is presented in Table 1 . The experiment was conducted at Melkassa Agricultural Research Center (MARC) using furrow irrigation. The site is situated in major snap bean growing belts located $117 \mathrm{~km}$ South East of Addis Ababa with geographic co-ordinates of $8^{\circ} 24^{\prime} \mathrm{N}$ latitude and $39^{\circ} 12^{\prime} \mathrm{E}$ longitude and at an altitude of 1550 m.a.s.l. The mean annual maximum and minimum temperature is about $28.6{ }^{\circ} \mathrm{C}$ and $13.8{ }^{\circ} \mathrm{C}$, respectively.

The experiment was laid out using (6x6) simple lattice design with plots size of $3.2 \mathrm{~m}^{2}$. Spacing was maintained to $40 \mathrm{~cm}$ and $10 \mathrm{~cm}$ between rows and plants in that order. Fertilizer at a rate of $100 \mathrm{~kg} / \mathrm{ha}$ DAP and $50 \mathrm{~kg} / \mathrm{ha}$ urea was applied. All other necessary cultural practices such as weeding and cultivation were applied to all plots uniformly.

Table1. List of snap bean genotypes used in the study

\begin{tabular}{|l|l|l|l|}
\hline No. & Genotypes & No. & Genotypes \\
\hline 1 & $\mathrm{~S}_{61}$ & 19 & PHA-22 \\
\hline 2 & HAB-408 & 20 & HAB-416 \\
\hline 3 & PHA-5782/93 & 21 & Odean \\
\hline 4 & BC $_{4.4}$ & 22 & HAB -423 \\
\hline 5 & HAB-419 $_{2}$ & 23 & HAB-431 \\
\hline 6 & Xera & 24 & Tema \\
\hline 7 & L $_{12}$ & 25 & S62 \\
\hline 8 & Palati & 26 & HAB-409 \\
\hline 9 & HAB-448 & 27 & HAB-410 \\
\hline 10 & PHA-24 & 28 & S6 \\
\hline 11 & HAB-430 & 29 & Back \\
\hline 12 & PHA-5780/93 & 30 & K3 \\
\hline 13 & HAB-414 & 31 & A20 \\
\hline 14 & Damater & 32 & HAB-405 \\
\hline 15 & PHA-6221/95 & 33 & PHA-6039/95 \\
\hline 16 & PHA-6048/95 & 34 & PHA-5783/93 \\
\hline 17 & HAB-436 & 35 & Polista \\
\hline 18 & PHA-404 & 36 & Containder \\
\hline
\end{tabular}

\section{DATA COLLECTION AND ANALYSIS}

Data on days to $50 \%$ emergence, $50 \%$ flowering and days to first picking were recorded on plot basis while vegetative growth, yield and yield contributing data were collected from ten randomly selected plants in a plot following descriptors developed by the International Plant Genetic Resources Institute.SAS package was used for analysis of variance while genotypic and phenotypic correlation coefficient and path analysis were computed using GENRES soft ware program from variance and covariance components following the formula of [13] as follows: 
Yosef Alemu et al. "Correlation and Path Analysis for Green Pod Yield and Its Components in Snap Bean (Phaseolus Vulgaris L.) Genotypes"

Phenotypic correlation $\left(\mathrm{r}_{\mathrm{p}}\right)=\frac{\text { Phenotypic covariance of traits } \mathrm{x} \text { and } \mathrm{y}}{\sqrt{\sigma^{2} \mathrm{ph} \mathrm{y} * \sigma^{2} \text { phy }}}$

Genotypic correlation $\left(\mathrm{r}_{\mathrm{g}}\right)=\frac{\text { Genotypic covariance of traits } \mathrm{x} \text { and } \mathrm{y}}{\sqrt{\sigma^{2} \mathrm{~g} x * \sigma^{2} \mathrm{gy}}}$

where, $\sigma^{2} \mathrm{phY}=$ phenotypic variance for character $\mathrm{Y}, \sigma^{2} \mathrm{ph} \mathrm{X}=$ phenotypic variance for character $\mathrm{X}$, $\sigma^{2} \mathrm{~g} X=$ genotypic variance for character $\mathrm{X}$ and $\sigma^{2} \mathrm{~g} \mathrm{Y}=$ genotypic variance for character $\mathrm{Y}$.

Based on genotypic correlation, path coefficient which refers to the direct and indirect effects of the yield attributing traits (independent character) on green pod yield (dependent character) was calculated following the method given by [3] as follows:

rij $=\mathrm{Pij}+\Sigma$ rikpkj, where, rij $=$ mutual association between the independent character (i) and dependent character (j) as measured by the genotypic correlation coefficients, Pij = direct effects of the independent character (i) on the dependent variable (j) as measured by the genotypic path coefficients, and $\Sigma$ rikpkj = summation of components of indirect effects of a given independent character (i) on a given dependent character $(\mathrm{j})$ via all other independent traits $(\mathrm{k})$.

The residual effect, which determines how best the causal factors account for the variability of the dependent factor, yield, was obtained using the formula:

$1=p^{2} \mathrm{R}+\Sigma$ pijrij, where, $\mathrm{p}^{2} \mathrm{R}$ is the residual effect and $\Sigma$ pijrij is summation of the product of direct effect of any variable and its correlation coefficient with yield.

\section{RESULTS AND DISCUSSION}

\section{Analysis of Variance}

Analysis of variance for 16 quantitative traits indicated highly significant $(\mathrm{P}<0.01)$ difference among genotypes for plant height, node number per plant, internode number per plant, days to $50 \%$ flowering and 50\% first picking, pod length, pod width and green pod yield per plant and significant differences $(\mathrm{P}<0.05)$ for $50 \%$ days to emergence, pod number per plant, leaf number and area per plant while non significant difference for primary branches per plant, single pod dry weight and secondary branches.

\section{Correlation of Green Pod Yield with other Traits}

Phenotypic $\left(r_{p}\right)$ and genotypic $\left(r_{g}\right)$ correlation between yield and yield related traits are presented in Table 2. Green pod yield per plant exhibited positive and significant correlation with green pod number per plant $\left(r_{g}=0.775, r_{p}=0.848\right)$, green pod length $\left(r_{g}=0.537, r_{p}=0.423\right)$ and green pod weight $\left(r_{g}=0.664, r_{p}=0.424\right)$. Similarly, [22] and [4] reported positive correlation of pod number per plant with green pod yield in snap bean. [15] and [23] also reported positive correlation of green pod length and green pod weight with green pod yield respectively. Leaf area per plant $\left(r_{g}=0.665\right)$ and pod dry weight $\left(r_{\mathrm{g}}=0.333\right)$ had significant positive association with green pod yield at genotypic level only. [12] reported positive correlation between yield and leaf area in soybean. The positive and significant correlation of these traits with green pod yield in the present finding revealed that selection for such traits is expected to bring about improvement in green pod yield per plant in snap bean.

Days to $50 \%$ flowering $\left(r_{g}=0.437\right)$ and days to first picking $\left(r_{g}=-0.557\right)$ exhibited negative and significant correlation with green pod yield per plant at genotypic level. At phenotypic level, only days to $50 \%$ flowering $\left(\mathrm{r}_{\mathrm{p}}=0.375\right)$ exhibited negative and significant association. [18] reported negative correlation of days to $50 \%$ flowering with green pod yield.

Table2. Genotypic correlation $\left(r_{g}\right)$ (above diagonal) and phenotypic correlation coefficients $\left(r_{p}\right)$ of yield and yield related traits of snap bean genotypes

\begin{tabular}{|l|l|l|l|l|l|l|l|}
\hline & $\mathbf{1}$ & $\mathbf{2}$ & $\mathbf{3}$ & $\mathbf{4}$ & $\mathbf{5}$ & $\mathbf{6}$ & $\mathbf{7}$ \\
\hline 1 & & 0.071 & $0.414^{* *}$ & $0.867^{* *}$ & $0.981^{* *}$ & $-0.438^{* *}$ & -0.139 \\
\hline 2 & 0.246 & & -0.157 & 0.145 & $0.552^{* *}$ & -0.087 & -0.067 \\
\hline 3 & $0.323^{*}$ & -0.062 & & 0.021 & $0.445^{* *}$ & $-0.451^{* *}$ & 0.177 \\
\hline 4 & $0.396^{*}$ & 0.080 & 0.059 & & $0.986^{* *}$ & $-0.508^{* *}$ & 0.099 \\
\hline 5 & $0.641^{* *}$ & 0.127 & 0.256 & 0.269 & & -0.228 & -0.062 \\
\hline 6 & $-0.194 \mathrm{n}$ & -0.043 & -0.183 & -0.169 & -0.204 & & -0.057 \\
\hline 7 & -0.030 & -0.138 & 0.158 & -0.080 & 0.002 & 0.048 & \\
\hline 8 & 0.147 & -0.195 & 0.199 & 0.024 & 0.085 & -0.183 & $0.389^{* *}$ \\
\hline
\end{tabular}


Yosef Alemu et al. "Correlation and Path Analysis for Green Pod Yield and Its Components in Snap Bean (Phaseolus Vulgaris L.) Genotypes"

\begin{tabular}{|l|l|l|l|l|l|l|l|}
\hline 9 & -0.090 & 0.232 & -0.227 & -0.137 & -0.240 & -0.024 & 0.100 \\
\hline 10 & -0.079 & 0.257 & 0.081 & -0.105 & -0.205 & -0.056 & -0.196 \\
\hline 11 & -0.062 & 0.145 & -0.007 & -0.068 & -0.069 & 0.024 & 0.013 \\
\hline 12 & 0.002 & 0.005 & -0.017 & -0.134 & -0.080 & -0.101 & -0.104 \\
\hline 13 & 0.237 & 0.187 & 0.079 & 0.136 & 0.096 & 0.128 & $-0.493^{* *}$ \\
\hline 14 & 0.151 & 0.307 & -0.050 & 0.066 & -0.038 & 0.093 & $-0.375^{* *}$ \\
\hline & $\mathbf{8}$ & $\mathbf{9}$ & $\mathbf{1 0}$ & $\mathbf{1 1}$ & $\mathbf{1 2}$ & $\mathbf{1 3}$ & $\mathbf{1 4}$ \\
\hline 1 & $0.440^{* *}$ & $-0.334^{*}$ & -0.274 & $-0.417^{* *}$ & -0.023 & $0.671^{* *}$ & 0.284 \\
\hline 2 & -0.024 & $0.531^{* *}$ & $0.515^{* *}$ & $0.503^{* *}$ & 0.308 & $0.436^{* *}$ & $0.665^{* *}$ \\
\hline 3 & 0.243 & $0.324^{*}$ & 0.148 & -0.115 & -0.019 & -0.023 & -0.211 \\
\hline 4 & $-0.468^{* *}$ & $-0.735^{* *}$ & $-0.976^{* *}$ & $-0.464^{* *}$ & -0.200 & $0.741^{* *}$ & 0.090 \\
\hline 5 & $0.436^{* *}$ & $-0.518^{* *}$ & -0.292 & -0.146 & 0.136 & $0.616^{* *}$ & 0.136 \\
\hline 6 & -0.262 & 0.092 & 0.247 & 0.175 & -0.195 & -0.268 & -0.113 \\
\hline 7 & $0.631^{* *}$ & 0.005 & -0.289 & -0.054 & -0.191 & $-0.727^{* *}$ & $-0.437^{* *}$ \\
\hline 8 & & -0.205 & $-0.548^{* *}$ & -0.248 & -0.037 & $-0.618^{* *}$ & $-0.557^{* *}$ \\
\hline 9 & -0.054 & & $0.638^{* *}$ & $0.589^{* *}$ & 0.111 & 0.048 & $0.664^{* *}$ \\
\hline 10 & -0.234 & 0.293 & & 0.035 & $0.454^{* *}$ & 0.092 & $0.333^{*}$ \\
\hline 11 & -0.129 & $0.364^{* *}$ & 0.234 & & $-0.777^{* *}$ & 0.176 & $0.537^{* *}$ \\
\hline 12 & 0.025 & 0.035 & 0.308 & -0.272 & & $-0.426^{* *}$ & -0.308 \\
\hline 13 & -0.304 & -0.098 & 0.172 & 0.231 & -0.113 & & $0.775^{* *}$ \\
\hline 14 & -0.292 & $0.424^{* *}$ & 0.281 & $0.423^{* *}$ & -0.128 & $0.848^{* *}$ & \\
\hline
\end{tabular}

**Significant at 1\%, * significant at 5\% probability level.1 = leaf number per plant, 2 = leaf area per plant $\left(\mathrm{cm}^{2}\right), 3=$ plant height $(\mathrm{cm}), 4=$ number of primary branches per plant, $5=$ number of secondary branches, $6=$ days to 50\% emergence, $7=$ days to 50\% flowering, $8=$ days to first picking, $9=$ single green pod weight $(\mathrm{g})$, 10 = single dry pod weight $(\mathrm{g}), 11=$ green pod length $(\mathrm{cm}), 12=$ green pod width $(\mathrm{mm}), 13=$ green pod number per plant and $14=$ green pod yield $(\mathrm{g})$ per plant

\section{Correlation among other Yield Contributing Traits}

\section{Phenotypic Correlation}

At phenotypic level, leaf number per plant showed positive and significant correlation with plant height, primary branches and secondary branches. Days to flowering also exhibited positive and significant correlation with days to first picking. There was also positive and significant correlation with green pod length and green pod weight. Green pod number per plant correlated negatively and significantly with days to $50 \%$ flowering. The rest traits showed no significant association to each other. In line with the present result, Shah [23] reported positive correlation of primary branches and plant height; days to 50\% flowering and pod number per plant; green pod length and single green pod weight.

\section{Genotypic Correlation}

Number of green pods per plant showed positive and significant correlation with number of primary branches per plant, number of secondary branches per plant, leaf area per plant and leaf number per plant at genotypic level. The rest traits such as days to $50 \%$ flowering, days to first picking and green pod width had negative and significant genotypic correlation with pod number per plant. In line with this result, [23] mentioned positive genotypic correlation between green pod number per plant and number of primary branches per plant. Similarly, [20] reported negative correlation between green pod number per plant and days to $50 \%$ flowering in snap bean.

Plant height depicted positive and significant correlation with leaf number per plant and secondary branches. Similar to this finding, [24] reported significant and positive correlation between plant height and secondary branches per plant at genotypic level.

Number of primary branches per plant exhibited positive and significant association with leaf number per plant and secondary branches per plant at genotypic level. The correlation was, however, negative and significant between primary branches per plant and green pod weight, dry pod weight and green pod length. Secondary branches also showed positive and significant association with leaf number per plant and leaf area per plant at genotypic level. Similarly, [17] and [7] reported negative correlation of primary branches with green pod length and green pod width respectively. 
Yosef Alemu et al. "Correlation and Path Analysis for Green Pod Yield and Its Components in Snap Bean (Phaseolus Vulgaris L.) Genotypes"

The association of days to $50 \%$ flowering with days to first picking at genotypic level was positive and significant. For most traits such as green pod length, green pod width, single green pod weight, green pod number per plant, leaf area, primary branches and leaf number per plant, days to $50 \%$ flowering exhibited negative association. In line with this report, [19] pointed out negative correlation between days to $50 \%$ flowering and green pod length, pod width, green pod weight and green pod number per plant.

Green pod width showed positive and significant correlation with dry pod weight at genotypic level. There was negative and significant association between green pod width and green pod length. Green pod length also exhibited positive and significant association with green pod weight, dry pod weight and leaf area per plant. It showed negative and significant correlation with leaf number and primary branches per plant. In accordance to the present finding, [19] reported positive correlation between green pod weight and green pod length.

\section{Path Coefficient Analysis}

Direct and indirect effect of different traits on green pod yield of snap bean genotypes at genotypic level is presented in Table 3. Number of green pod per plant had exerted the highest positive direct effect on green pod yield per plant which led to positive and significant correlation of this trait with green pod yield per plant. The second maximum positive direct effect was exerted by single green pod weight. These traits ultimately affected green pod yield mainly with their substantial positive direct effects. Similarly, [24] reported positive direct effects of green pod number per plant and single green pod weight on green pod yield per plant.

Plant height showed the highest negative direct effect on green pod yield per plant which contributed for its negative correlation with green pod yield. The next maximum negative direct effect was exerted by days to $50 \%$ emergence. The negative direct effect of plant height on green pod yield per plant is in accordance with the previous report of [9].

The maximum negative indirect effect on green pod yield per plant was exhibited by days to $50 \%$ flowering through green pod number while the second and the third maximum negative indirect effects were exerted by days to first picking and green pod width through the same character respectively. That means, these traits affected green pod yield per plant via their negative indirect effects on green pod number per plant. Similarly, [24] reported negative indirect effect of days to $50 \%$ flowering and green pod width on green pod yield per plant via green pod number per plant.

The magnitude of residual effect $(0.21)$ indicated that traits included in the path analysis explained about $79 \%$ of the variation in green pod yield. However, the remaining variation in green pod yield $(21 \%)$ can be attained by incorporating other yield related traits in the path analysis as far as studies involving association of traits is concerned.

Table3. Estimates of direct (bold diagonal) and indirect effect (off diagonal) for different traits on green pod yield in snap bean genotypes tested at Melkassa.

\begin{tabular}{|l|l|l|l|l|l|l|l|l|l|l|l|l|l|l|}
\hline & $\mathbf{1}$ & $\mathbf{2}$ & $\mathbf{3}$ & $\mathbf{4}$ & $\mathbf{5}$ & $\mathbf{6}$ & $\mathbf{7}$ & $\mathbf{8}$ & $\mathbf{9}$ & $\mathbf{1 0}$ & $\mathbf{1 1}$ & $\mathbf{1 2}$ & $\mathbf{1 3}$ & $\mathbf{R g}$ \\
\hline 1 & $\mathbf{- 0 . 1 1 8}$ & 0.003 & -0.190 & -0.002 & 0.260 & 0.140 & -0.026 & 0.051 & -0.057 & -0.148 & -0.094 & 0.003 & 0.462 & 0.284 \\
\hline 2 & 0.008 & $-\mathbf{0 . 0 4 8}$ & 0.072 & -0.0003 & -0.121 & 0.028 & -0.012 & 0.003 & 0.091 & 0.277 & 0.114 & -0.047 & 0.3001 & $0.665^{* *}$ \\
\hline 3 & -0.049 & 0.008 & $\mathbf{- 0 . 4 5 8}$ & 0.001 & 0.097 & 0.144 & 0.033 & 0.028 & -0.056 & 0.079 & -0.026 & 0.003 & -0.016 & -0.211 \\
\hline 4 & -0.102 & -0.007 & 0.009 & $\mathbf{- 0 . 0 0 2}$ & 0.283 & 0.162 & 0.018 & -0.054 & -0.126 & -0.526 & -0.105 & 0.030 & 0.509 & 0.090 \\
\hline 5 & -0.139 & 0.027 & -0.204 & -0.003 & $\mathbf{0 . 2 3 0}$ & 0.073 & -0.011 & 0.050 & -0.089 & -0.156 & -0.033 & -0.021 & 0.424 & 0.136 \\
\hline 6 & 0.052 & 0.004 & 0.206 & 0.001 & -0.050 & $-\mathbf{0 . 3 2 0}$ & -0.011 & -0.030 & 0.016 & 0.133 & 0.039 & 0.0296 & -0.184 & -0.113 \\
\hline 7 & 0.016 & 0.003 & -0.081 & -0.0002 & -0.014 & 0.018 & $\mathbf{0 . 1 8 5}$ & 0.073 & 0.001 & -0.156 & -0.012 & 0.029 & -0.500 & $-0.437^{* *}$ \\
\hline 8 & -0.052 & -0.001 & -0.111 & 0.001 & 0.095 & 0.084 & 0.117 & $\mathbf{0 . 1 1 6}$ & -0.035 & -0.295 & -0.056 & 0.006 & -0.425 & $-0.557^{* *}$ \\
\hline 9 & 0.039 & -0.026 & 0.148 & 0.002 & -0.114 & -0.029 & 0.001 & -0.024 & $\mathbf{0 . 1 7 2}$ & 0.344 & 0.133 & -0.017 & 0.033 & $0.664^{* *}$ \\
\hline 10 & 0.032 & -0.024 & -0.068 & 0.002 & -0.064 & -0.079 & -0.053 & -0.063 & 0.110 & $\mathbf{0 . 5 3 9}$ & 0.008 & 0.069 & 0.063 & $0.333^{*}$ \\
\hline 11 & 0.049 & -0.024 & 0.053 & 0.001 & -0.032 & -0.056 & -0.010 & -0.029 & 0.101 & 0.019 & $\mathbf{0 . 2 2 6}$ & 0.118 & 0.121 & $0.537^{* *}$ \\
\hline 12 & 0.003 & -0.025 & 0.009 & 0.0004 & 0.030 & 0.062 & -0.035 & -0.004 & 0.019 & 0.245 & -0.176 & $-\mathbf{0 . 1 5 2}$ & -0.293 & -0.308 \\
\hline 13 & -0.079 & -0.021 & 0.011 & -0.002 & 0.136 & 0.085 & -0.135 & -0.071 & 0.008 & 0.049 & 0.0399 & 0.065 & $\mathbf{0 . 6 8 8}$ & $0.775^{* *}$ \\
\hline
\end{tabular}

Residual $=0.21,1=$ leaf number per plant, $2=$ leaf area per plant $\left(\mathrm{cm}^{2}\right), 3=$ plant height $(\mathrm{cm}), 4=$ number of primary branches per plant, $5=$ number of secondary branches, $6=$ days to $50 \%$ emergence, $7=$ days to $50 \%$ flowering, $8=$ days to first picking, $9=$ single green pod weight $(\mathrm{g}), 10=$ single dry pod weight $(\mathrm{g}), 11=$ green pod length $(\mathrm{cm}), 12=$ green pod width $(\mathrm{mm})$ and $13=$ green pod number per plant 
Yosef Alemu et al. "Correlation and Path Analysis for Green Pod Yield and Its Components in Snap Bean (Phaseolus Vulgaris L.) Genotypes"

\section{CONCLUSIONS}

Positive and significant genotypic correlation was observed between green pod yield with number of pod per plant, single green pod weight, pod dry weight, pod length and leaf area per plant while significant negative genotypic correlation was found between green pod yield and days to $50 \%$ flowering and days to first picking. Genotypic path analysis also showed that pod number per plant exerted the maximum positive direct effect on green pod yield followed by single green pod weight while plant height exhibited maximum negative direct effect. Higher genotypic correlations than corresponding phenotypic correlations among most of the traits indicated the prevalence of genetic variation in expression of the traits. In few cases, however, the magnitudes of phenotypic correlation coefficients were higher than their corresponding genotypic correlation coefficients suggesting the importance of environmental effects. Generally, selection for traits such as green pod number per plant, green pod length and pod weight (green and dry) could improve green pod yield snap bean.

\section{ACKNOWLEDGEMENTS}

The authors acknowledge Ethiopian Institute of Agricultural Research (EIAR) for financial support and technicians of vegetable crops research at Melkassa Agricultural Research Center (MARC) who contributed to the accomplishment of this experiment.

\section{REFERENCES}

[1] CIAT, 2006. Highlights of CIAT in Africa. Series. No.31.

[2] David. D. Kirkby, R. and Kasozi, S. 2000. Assessing the impact of bush bean varieties on poverty reduction in Sub-Saharan Africa: Evidence from Uganda. Network on bean research in Africa. Series. No. 31, CIAT, Kampala, Uganda.

[3] Dewey, D.R. and Lu, K.H. 1959. A correlation and path coefficient analysis of components of crested wheat grass kernel production. J. Agronomy. 51: 515-518.

[4] Dursun, A. 2007. Variability, heritablity and correlation study in bean (Phaseolus ulgaris L.) genotypes. J. Agri. Sci. 3 (1):12-16.

[5] FAOSTAT, 2013. Statistical Database of the Food and Agriculture of the United Nations.

[6] Getachew Abate., 2006. The market for fresh snap beans. The Strategic Marketing Institute, Working Paper.pp.6-8.

[7] Govanakoppa, R. 2001. Genetic divergence, generation mean analysis and stress resistance breeding in french bean (Phaseolus vulgaris L.). M.Sc. (Agri.) Thesis presented to the University of Agricultural Sciences, Dharwad.

[8] Hussein, 2015. Response of Snap Bean Cultivars to Rhizobium Inoculation under Dryland Agriculture in Ethiopia. Agronomy Journal, 5(3), 291-308; doi:10.3390/agronomy5030291

[9] Joshi, B.D. and Mehra, K.L. 1983. Genetic variability in french bean. J.Progressive Horticulture, 15: 109-111.

[10] Lemma Dessalegn, 2003. Snap bean production and research status in Ethiopia. Research report.

[11] Lemma Dessalegn, Selamawit Ketema, Abiyot Aragaw and Shimelis Aklilu, 2006. Varietal development of major vegetables in the rift valley region. Proceeding of the Inaugural and first Ethiopian horticultural science society (EHSS), 27-30 March 2006. Addis Ababa, Ethiopia.

[12] Malik, A., Ashraf, M., Qureshi, S.A. and Ghafoor, A. 2007. Assessment of genetic variability, correlation and path analyses for yield and its components in soybean. J. Bot. 39(2): 405-413.

[13] Miller, P.A., Williams, C.Robinson, H.F.and Comstock, R.E.1958. Estimates of genotypic and environmental variances and co-variances in upland cotton and their implications in selection. $J$. Agronomy, 50:126 -131.

[14] MoARD, 2014. Plant variety release, protection and seed quality control directorate, crop variety register. Issue no. 16

[15] Pande, G.K., Seth, J.N. and Lal, S.D.1973. Variability and correlation studies in pole french bean in relation to green pod yield. J. The Punjab Horticultural, 23: 126-131. 
Yosef Alemu et al. "Correlation and Path Analysis for Green Pod Yield and Its Components in Snap Bean (Phaseolus Vulgaris L.) Genotypes"

[16] Santalla, M., Miguel, A. F., Rodino, A., Paula I. M. and Antonio, M. R. 1999. Breeding for culinary and nutritional quality of common bean (Phaseolus vulgarisL.). pp.134-134.

[17] Singh, A.K. 1993. Genetic variability and correlation studies in french bean. Haryana Journal of Horticultural Sciences, 22(3): 235-239.

[18] Singh, B.K., Singh, B.P. and Ram, H.H. 2000. Variability and correlation studies in bush type french Bean (Phaseolus vulgaris L.) in relation to green pod yield. Progressive Horticulture, 32(2): 176-182.

[19] Singh, D.N., Nandi, A. and Tripathy, P. 1994. Genetic variability and character association in french bean (Phaseolus vulgaris). Indian Journal of Agricultural Sciences, 64(2): 114-116.

[20] Singh, K.P., Singh, A.K. and Yadav, V.K. 2004. Character association for seed yield in rajmash bean (Phaseolus vulgaris L.). Vegetable Science, 31(2): 172-174.

[21] .Singh, S.P. 1982. A key for identification of different growth habits of Phaseolus vulgarisL. Annual report of Bean Improvement Cooperative 25:92-95.

[22] Shaban, N. 2005. Analysis of the correlation and regression coefficients of the interaction between yield and some parameters of snap beans plants.J. Sci. 3(6):27-31.

[23] Shah, D., Pant, C.C. and Solanki, S.S. 1999.Studies on agronomic traits and genetic parameters in french bean (Phaseolus vulgaris L.). Progressive Horticulture, 31(3-4): 194-198.

[24] Smitha. 2005. Divergence and stability studies in french bean (Phaseolus vulgaris L.). MSC Thesis presented to The University of Agricultural Sciences, 